\title{
ANALISIS FAKTOR-FAKTOR YANG MEMPENGARUHI PEMBERIAN ASI EKSKLUSIF DI PUSKESMAS UMBULHARJO I YOGYAKARTA
}

\author{
ANALYSIS OF FACTORS THAT INFLUENCE EXCLUSIVE ASI ASSUMPTIONS \\ IN UMBULHARJO I PUSKESMAS YOGYAKARTA
}

Nidatul Khofiyah

Fakultas Ilmu Kesehatan, Universitas 'Aisyiyah Yogyakarta

Email : nidatulkhofiyah@unisayogya.ac.id

\begin{abstract}
ABSTRAK
Kota Yogyakarta menempati urutan terendah kedua cakupan ASI eksklusif setelah Kabupaten Gunung Kidul. Puskesmas Umbulharjo I memiliki cakupan ASI Eksklusif terendah di Kota Yogyakarta.Rendahnya presentase pemberian ASI Ekslusif di Indonesia ini berhubungan dengan kurangnya pengetahuan masyarakat di bidang kesehatan dan minimnya dukungan dari berbagai pihak. Penelitian ini bertujuan untuk menganalisis faktor-faktor yang mempengaruhi pemberian ASI Eksklusif di Puskesmas Umbulharjo I Yogyakarta.Jenis penelitian ini adalah kuantitatif dengan desain penelitian observasional analitik dengan desain Crossectional. Sampel dalam penelitian ini adalah ibu yang memiliki bayi umur 6-12 bulan yang ada di wilayah kerja Puskesmas Umbulharjo I Yogyakarta yang memenuhi criteria inklusi dan eksklusi.Teknik analisa data menggunakan uji chi square dan regresi logistik. Penelitian ini menunjukkan berdasarkan Variabel yang paling berpengaruh adalah variabel pekerjaan ibu dengan nilai uji statistic regresi logistic didapatkan $p$-value $=0,000$ dan nilai $O R=5,67$ (CI: 2,29-14,0) dapat diartikan bahwa ibu yang tidak bekerja berpeluang 5,67 kali untuk berhasil dalam memberikan ASI Ekslusif dibandingkan ibu yang bekerja. Variabel kedua yang paling berpengaruh adalah variabel pengetahuan ibu dengan nilai uji statistic regresi logistic didapatkan p-value $=0,006$ dan nilai OR = 9,42 (CI: 1,89-46,9) dapat diartikan bahwa ibu yang tahu tentang ASI Ekslusif berpeluang 9,42 kali untuk berhasil dalam memberikan ASI Ekslusif dibandingkan ibu tidak tahu mengenai ASI Ekslusif. Puskesmas Umbulharjo I Yogyakarta diharapkan dapat memberikan penyuluhan terkait ASI Eksklusif untuk meningkatkan pengetahuan para ibu yang mempunyai balita terutama di wilayah kerja Puskesmas.
\end{abstract}

Kata Kunci: ASI Eksklusif, tumbuh kembang, faktor pemberian ASI Eksklusif

\section{ABSTRACT}

The city of Yogyakarta ranks second only to exclusive breastfeeding coverage after Gunung Kidul Regency. Umbulharjo Health Center I has the lowest exclusive ASI coverage in Yogyakarta City. The low percentage of exclusive breastfeeding in Indonesia is related to the lack of public knowledge in the health sector and the lack of support from various parties. This study aims to analyze the factors that influence exclusive breastfeeding at Umbulharjo I Public Health Center Yogyakarta. The type of this study is quantitative with observational analytic research design with Crossectional design. The sample in this study were mothers who had 6-12 month old infants in the working area of the Yogyakarta Umbulharjo I Health Center that met the inclusion and exclusion criteria. Data analysis techniques used the chi square test and logistic regression. This study shows based on the most influential variable is the mother's work variable with the logistic regression test value obtained p-value $=0,000$ and OR value $=5.67$ (CI: 2.29-14.0) can be interpreted that mothers who do not work have a chance 5.67 times to succeed in giving exclusive breastfeeding compared to working mothers. The second most influential variable is the mother's knowledge variable with the logistic regression statistical value obtained p-value $=0.006$ and OR $=9.42$ (CI: 1.89-46.9) can be interpreted that mothers who know about Exclusive Breastfeeding have a chance 9,42 times to succeed in giving exclusive breastfeeding compared to mothers who do not know about exclusive breastfeeding. Yogyakarta's Umbulharjo I Health Center is expected to be able to provide counseling regarding Exclusive Breastfeeding to increase the knowledge of mothers who have toddlers, especially in the Puskesmas working area. 
Keywords: Exclusive breastfeeding, growth and development, factors of exclusive breastfeeding

\section{PENDAHULUAN}

Upaya membangun manusia seutuhnya diselenggarakan melalui upaya kesehatan anak yang dilakukan sedini mungin. Upaya kesehatan anak dilakukan sejak anak masih dalam kandungan sampai lima tahun pertama kehidupannya. Tujuan upaya kesehatan anak untuk mempertahankan kelangsungan dan meningkatkan kualitas hidup anak supaya mencapai pertumbuhan dan perkembangan secara optimal baik fisik, mental, emosional, sosial dan mempunyai intelegensia majemuk sesuai dengan potensi genetiknya (Rusmil, 2012).

ASI adalah makanan bayi yang menjadi ASI Eksklusif memiliki kontribusi yang besar terhadap daya tahan tubuh anak sehingga anak yang diberi ASI Eksklusif tidak mudah sakit. Hal tersebut sesuai dengan kajian dan fakta global "The Lancet Breastfeeding Series" 2016 telah membuktikan bahwa menyusui eksklusif menurunkan angka kematian karena infeksi sebanyak $88 \%$ pada bayi berusia kurang dari 3 bulan, Sebanyak 31,36\% (82\%) dari 37,94\% anak sakit karena tidak menerima ASI ekslusif. ASI Eksklusif berkontribusi dalam menurunkan risiko obese, BBLR, Stunting dan penyakit kronis (Patel dan Gedam, 2013).

Berdasarkan hasil penelitian World Breastfeeding Trends Initiative (WBTI) tahun 2012, hanya 27,5 persen ibu di Indonesia yang berhasil memberi ASI eksklusif selama 6 bulan. Rendahnya presentase pemberian ASI Ekslusif di Indonesia ini berhubungan dengan kurangnya pengetahuan masyarakat di bidang kesehatan dan minimnya dukungan dari berbagai pihak (Wahana Visi Indonesia, 2015).

Berdasarkan data profil kesehatan Propinsi D.I. Yogyakarta 3 tahun terakhir cakupan ASI eksklusif tahun 2013 sebesar (66,08\%), tahun 2014 (70,79\%), dan tahun 2015 (71,62\%). Meskipun mengalami peningkatan tetapi belum mampu mencapai target nasional sebesar $80 \%$. Tahun 2015 Presentasi ASI tertinggi di Kabupaten Sleman yaitu (80,62\%), Kulon Progo (74,97\%), Bantul (74,73\%), Kota Yogyakarta (60,87\%), dan Gunung Kidul (58,52\%) (Profil Dinkes DIY, 2015). Kota Yogyakarta menempati urutan terendah kedua cakupan ASI eksklusif setelah Kabupaten Gunung Kidul.

Pemberian ASI eksklusif pada bayi bukan hanya tanggung jawab ibu. Dukungan suami, keluarga dan masyarakat serta pihak terkait lainnya sangat dibutuhkan untuk meningkatkan kembali pemberian ASI eksklusif pada bayi. Kepala Keluarga, dalam hal ini suami juga memiliki tanggung jawab besar untuk memberikan dukungan (Pemprov DKI Jakarta, 2010).Dalam penelitian di Brazil, Monica (2010) memperlihatkan bahwa peran keluarga sangat menentukan perilaku ibu dalam memberikan ASI eksklusif kepada anaknya.

Data Dinas Kesehatan Kota Yogyakarta (2016) pada tahun 2015 Puskemas yang terendah cakupan ASI eksklusifnya adalah Puskesmas Umbul Harjo I dengan jumlah 727 bayi hanya $333(45,80 \%)$ bayi yang diberikan ASI eksklusif. Dari hasil studi pendahuluan didapatkan jumlah ibu yang memberikan ASI di Puskesmas Umbulharjo I tahun 2016 sebanyak 375 ibu, dan yang memberikan 
ASI eksklusif hanya $133 \mathrm{ibu}(35,4 \%)$, yang menunjukkan bahwa praktik pemberian ASI eksklusif di Puskesmas Umbulharjo I masih jauh dari target cakupan nasional $(80 \%)$.

\section{METODE PENELITIAN}

Penelitian ini penelitian ini adalah kuantitatif dengan desain penelitian observasional analitik denagn desain Crossectional. Sampel dalam penelitian ini adalah ibu yang memiliki bayi umur 6-12 bulan yang ada di wilayah kerja Puskesmas Umbulharjo I Yogyakarta yang memenuhi criteria inklusi dan eksklusi. Pengumpulan data menggunakan data primer berupa kuesioner. Teknik analisa data menggunakan uji chi square dan regresi logistik.

\section{HASIL DAN PEMBAHASAN}

1. Analisis Univariat

a. Gambaran pemberian ASI Ekslusif di Puskesmas Umbulharjo I Yogyakarta

Tabel 1. Distribusi Frekuensi Pemberian ASI Ekslusif di Puskesmas Umbulharjo I Yogyakarta

\begin{tabular}{cccc}
\hline No & $\begin{array}{c}\text { ASI } \\
\text { Ekslusif }\end{array}$ & Frekuensi & Persentase \\
\hline 1 & Ya & 72 & $44,4 \%$ \\
2 & Tidak & 90 & $55,6 \%$ \\
& Total & 162 & $100 \%$ \\
\hline
\end{tabular}

Berdasarkan tabel 1 dapat diketahui bahwa sebagian besar responden tidak memberikan ASI Eksklusif yaitu sebanyak 90 responden atau 55,6\%.

b. Gambaran Paritas di Puskesmas Umbulharjo Umbulharjo I Yogyakarta

Tabel 2. Distribusi Frekuensi Paritas di Puskesmas Umbulharjo I Yogyakarta

\begin{tabular}{cccc}
\hline No & Paritas & Frekuensi & Persentase \\
\hline 1 & Anak $>1$ & 92 & $56,8 \%$ \\
2 & Anak 1 & 70 & $43,2 \%$ \\
& Total & 162 & $100 \%$ \\
\hline
\end{tabular}

Berdasarkan tabel 2 dapat diketahui bahwa sebagian besar responden mempunyai paritas atau anak lebih dari 1 yaitu sebanyak 92 responden atau $56,8 \%$.

c. Gambaran Pendidikan ibu di Puskesmas Umbulharjo I Yogyakarta

Tabel 3. Distribusi Frekuensi Pendidikan Ibu di Puskesmas Umbulharjo I Yogyakarta

\begin{tabular}{cccc}
\hline No & $\begin{array}{c}\text { Pendidikan } \\
\text { ibu }\end{array}$ & Frekuensi & Persentase \\
\hline 1 & Tinggi & 125 & 77,2 \\
2 & Rendah & 37 & 22,8 \\
& Total & 162 & $100 \%$ \\
\hline
\end{tabular}


Berdasarkan tabel 3 dapat diketahui bahwa sebagian besar responden mempunyai pendidikan tinggi yaitu sebanyak 125 responden atau 77,2\%.

d. Gambaran Pekerjaan ibu di Puskesmas Umbulharjo I Yogyakarta

Tabel 4. Distribusi Frekuensi Pekerjaan Ibu di Puskesmas Umbulharjo I Yogyakarta

\begin{tabular}{cccc}
\hline No & $\begin{array}{c}\text { Pekerjaan } \\
\text { ibu }\end{array}$ & Frekuensi & Persentase \\
\hline 1 & Tidak & 76 & $46,9 \%$ \\
& bekerja & & \\
2 & Bekerja & 86 & $53,1 \%$ \\
& Total & 162 & $100 \%$ \\
\hline
\end{tabular}

Berdasarkan tabel 4 dapat diketahui bahwa sebagian besar responden bekerja yaitu sebanyak 86 responden atau $53,1 \%$.

e. Gambaran dukungan keluarga pada ibu di Puskesmas Umbulharjo I Yogyakarta

Tabel 5. Distribusi Frekuensi Dukungan Keluarga pada Ibu di Puskesmas Umbulharjo I Yogyakarta

\begin{tabular}{cccc}
\hline No & Dukungan keluarga & Frek & Persentase \\
\hline 1 & Mendukung & 134 & $82,7 \%$ \\
2 & Tidak mendukung & 28 & $17,3 \%$ \\
& Total & 162 & $100 \%$ \\
\hline
\end{tabular}

Berdasarkan tabel 5 dapat diketahui bahwa sebagian besar responden mempunyai keluarga yang mendukung yaitu sebanyak 134 responden atau $82,7 \%$.

f. Gambaran Pengetahuan pada ibu di Puskesmas Umbulharjo I Yogyakarta

Tabel 6. Distribusi Frekuensi Pengetahuan pada Ibu di Puskesmas Umbulharjo I Yogyakarta

\begin{tabular}{cccc}
\hline No & $\begin{array}{c}\text { Pengetahuan } \\
\text { ibu }\end{array}$ & Frekuensi & Persentase \\
\hline 1 & Tahu & 137 & $84,6 \%$ \\
2 & Tidak tahu & 25 & $15,4 \%$ \\
& Total & 162 & $100 \%$ \\
\hline
\end{tabular}

Berdasarkan tabel 6 dapat diketahui bahwa sebagian besar responden tahu tentang ASI Ekslusif yaitu sebanyak 137 responden atau 84,6\%.

\section{Analisis Bivariat}

a. Hubungan Paritas dengan Keberhasilan ASI Eksklusif di Puskesmas Umbulharjo I Yogyakarta

Tabel 7. Tabulasi Silang Hubungan Paritas dengan Keberhasilan ASI Eksklusif di Puskesmas Umbulharjo I Yogyakarta

\begin{tabular}{|c|c|c|c|c|c|c|c|c|}
\hline \multirow{3}{*}{ Paritas } & \multicolumn{4}{|c|}{ ASI Ekslusif } & \multirow{3}{*}{ Total } & \multirow{3}{*}{ P value } & \multirow{3}{*}{ OR } & \multirow{3}{*}{ CI } \\
\hline & \multicolumn{2}{|c|}{$\mathbf{Y a}$} & \multicolumn{2}{|c|}{ Tidak } & & & & \\
\hline & $\mathbf{F}$ & $\%$ & $\mathbf{F}$ & $\%$ & & & & \\
\hline Anak $>1$ & 30 & $32,6 \%$ & 62 & $67,4 \%$ & 92 & & 0,32 & \\
\hline
\end{tabular}




\begin{tabular}{llllllll}
\hline Anak 1 & 42 & $60,0 \%$ & 28 & $40,0 \%$ & 70 & 0,001 & $0,16-0,61$ \\
\hline
\end{tabular}

Berdasarkan tabel 7 dari Hasil uji Chi Squere menunjukkan bahwa nilai $p$-value 0,001 . Oleh karena $p$-value $<\alpha(0,05)$ artinya ada hubungan antara Paritas dengan Keberhasilan ASI Eksklusif di Puskesmas Umbulharjo I Yogyakarta.

Berdasarkan karakteristik paritas pada penelitian ini sebagian besar responden memiliki paritas lebih dari 1 (multipara) sejumlah 92 responden (56,8\%), hal ini sesuai dengan Risnaningsih (2012) yang menyatakan bahwa kemandirian seorang ibu pasca melahirkan akan berbeda antara jumlah paritas satu dengan yang lebih, dikarenakan ibu yang mempunyai paritas yang lebih banyak mempunyai pengalaman untuk memberikan ASI.

Hasil uji Chi Squere menunjukkan bahwa nilai p-value 0,001, artinya ada hubungan antara paritas dengan keberhasilan ASI Eksklusif di Puskesmas Umbulharjo I Yogyakarta. Paritas juga berhubungan dengan pengalaman ibu dalam menyusui dan merawat bayi. Pernyataan tersebut didukung oleh beberapa hasil penelitian yang menyebutkan bahwa sebagian ibu nifas primipara dengan sedikit pengalaman secara nyata dapat meningkatkan stress dan kecemasan. Hal ini disebabkan karena pada ibu primipara belum memiliki pengalaman dalam persalinan dan merawat bayi (Zanardo, 2009).

b. Hubungan Pendidikan ibu dengan Keberhasilan ASI Eksklusif Puskesmas Umbulharjo I Yogyakarta

Tabel 8. Tabulasi Silang Hubungan Pendidikan ibu dengan Keberhasilan ASI Eksklusif Puskesmas Umbulharjo I Yogyakarta

\begin{tabular}{ccccccccc}
\hline \multirow{2}{*}{ Pendidikan } & \multicolumn{9}{c}{ Ya } & \multicolumn{2}{c}{ Tidak } & Total & P value & OR & CI \\
& F & \% & F & \% & & & & \\
\hline Tinggi & 61 & $48,8 \%$ & 64 & $51,2 \%$ & 125 & \multirow{2}{*}{0,040} & 2,25 & $1,02-4,95$ \\
Rendah & 11 & $29,7 \%$ & 26 & $70,3 \%$ & 37 & & & \\
\hline
\end{tabular}

Berdasarkan tabel 8 dari Hasil uji Chi Square menunjukkan bahwa nilai $p$-value 0,040 . Oleh karena $p$-value $<\alpha(0,05)$ artinya ada hubungan antara Pendidikan ibu dengan Keberhasilan ASI Eksklusif di Puskesmas Umbulharjo I Yogyakarta.

Hasil penelitian menunjukkan bahwa sebagian besar responden mempunyai pendidikan tinggi yaitu sebanyak 125 responden atau 77,2\%. Hasil uji Chi Square menunjukkan bahwa nilai p-value 0,040. Oleh karena $p$-value $<\alpha(0,05)$ artinya ada hubungan antara Pendidikan ibu dengan Keberhasilan ASI Eksklusif di Puskesmas Umbulharjo I Yogyakarta.

Winkjosastro (2010) menyatakan bahwa pendidikan akan membuat seseorang terdorong untuk ingin tahu, untuk mencari pengalaman dan untuk mengorganisasikan pengalaman sehingga informasi yang diterima akan menjadi pengetahuan. Seseorang berpendidikan tinggi akan lebih 
mudah menerima suatu ide baru dibanding dengan orang yang berpendidikan rendah.

Berdasarkan hasil penelitian yang dilakukan Saraswati (2007) menunjukan bahwa pengetahuan yang tinggi maka wawasan dan usaha untuk mecari informasi akan lebih luas, karena orang yang memiliki dasar pendidikan yang tinggi lebih mudah mengerti dan memahami informasi yang diterimanya bila dibanding dengan respoden yang berpendidikan lebih rendah. Dalam rangka pembinaan dan peningkatan perilaku kesehatan masyarakat lebih tepat dilaksanakan edukasi (pendidikan kesehatan).

c. Hubungan Pekerjaan ibu dengan Keberhasilan ASI Eksklusif di Puskesmas Umbulharjo I Yogyakarta

Tabel 9. Tabulasi Silang Hubungan Pekerjaan ibu dengan Keberhasilan ASI Eksklusif

\begin{tabular}{|c|c|c|c|c|c|c|c|c|}
\hline \multirow{3}{*}{ Pekerjaan } & \multicolumn{4}{|c|}{ ASI Ekslusif } & \multirow{3}{*}{ Total } & \multirow{3}{*}{ P value } & \multirow{3}{*}{ OR } & \multirow{3}{*}{ CI } \\
\hline & \multicolumn{2}{|r|}{ Ya } & \multicolumn{2}{|c|}{ Tidak } & & & & \\
\hline & $\mathbf{F}$ & $\%$ & $\mathbf{F}$ & $\%$ & & & & \\
\hline \multirow{2}{*}{$\begin{array}{c}\text { Tidak } \\
\text { bekerja } \\
\text { Bekerja }\end{array}$} & 50 & $65,8 \%$ & 26 & $34,2 \%$ & 76 & \multirow{2}{*}{0,000} & \multirow[t]{2}{*}{5,59} & \multirow{2}{*}{$2,84-11,0$} \\
\hline & 22 & $25,6 \%$ & 64 & $74,4 \%$ & 86 & & & \\
\hline
\end{tabular}

Berdasarkan table 9 dari Hasil uji Chi Squere menunjukkan bahwa nilai $p$-value 0,000 . Oleh karena $p$-value $<\alpha(0,05)$ artinya ada hubungan antara Pekerjaan ibu dengan Keberhasilan ASI Eksklusif di Puskesmas Umbulharjo I Yogyakarta .

Hasil penelitian menemukan bahwa sebagian besar responden di wilayah kerja puskesmas Umbulharjo I Kota Yogyakarta bekerja yaitu sebanyak 86 orang $(53,1 \%)$ dan sebagian yang bekerja sebanyak 76 orang $(46,9 \%)$. Dalam hal ini berarti bahwa ibu menyusui lebih banyak yang bekerja dibandingkan yang tidak bekerja.

Ibu yang bekerja untuk membantu perekonomian keluarga saat ini banyak sekali. Peraturan jam kerja yang ketat, lokasi tempat tinggal yang jauh dari tempat kerja, atau tidak ada fasilitas kendaraan pribadi menjadi faktor yang menghambat ibu untuk memberikan ASI kepada bayinya. Faktor lainnya adalah ibu yang bekerja fisik pasti akan cepat lelah, sehingga tidak punya tenaga lagi untuk menyusui, ditempat kerja jarang tersedia fasilitas tempat untuk memerah ASI yang memadai (Damayanti, 2010).

Alasan responden tidak memberikan ASI eksklusif dikarenakan alasan harus kembali bekerja sehingga harus meninggalkan bayinya dirumah dan tidak bisa memberikan ASI eksklusif. Sebagian lagi menyatakan bahwa produksi ASI sedikit dan bayi tetap menangis meskipun sudah disusui sehingga mereka memberikan makanan/minuman lain kepada bayinya. Alasan para ibu yang bekerja tidak memberikan ASI eksklusif tersebut bisa diatasi apabila mereka mau aktif mencari informasi tentang ASI eksklusif meskipun harus meninggalkan bayinya dalam waktu lama. Para ibu bisa memerah ASI 
setiap sebelum bekerja atau jika ada waktu luang dan menyimpan ASI perah didalam lemari pendingin.

Hasil uji statistic regresi logistic didapatkan $p$-value $=0,000$ dan nilai $\mathrm{OR}=5,67$ (CI: 2,29-14,0) dapat diartikan bahwa ibu yang tidak bekerja berpeluang 5,67 kali untuk berhasil dalam memberikan ASI Ekslusif dibandingkan ibu yang bekerja. Di Negara berkembang ibu bekerja demi menambah hasil pendapatan keluarga merupakan keharusan. Di Negara yang sedang berkembang seperti Indonesia tingkat kemiskinan semakin meningkat dan merebaknya pengangguran menjadi salah satu alasan mengapa banyak ibu yang bekerja (Dalimunthe, 2011).

Meskipun ibu bekerja diluar rumah, ibu harus tetap memberikan ASI secara eksklusif karena ibu yang bekerja diluar rumah mempunyai lingkungan yang lebih luas dan informasi tentang ASI eksklusif yang didapat juga akan lebih banyak, sehingga dapat merubah perilaku ibu untuk memilih memberikan ASI saja kepada bayinya (Notoatmodjo, 2012). Kenaikan tingkat partisipasi wanita dalam angkatan kerja serta cuti yang kurang memadai bagi para ibu yang bekerja menyebabkan turunnya kesediaan menyusui dan lamanya menyusui (Indrawati, 2012). Pekerjaan bukan alasan untuk menghentikan pemberian ASI secara eksklusif selama 6 bulan. Dengan pengetahuan yang benar tentang menyusui, perlengkapan memerah ASI dan dukungan lingkungan kerja, seorang ibu yang bekerja dapat tetap memberikan ASI secara eksklusif (Novia, 2012).

Hasil uji Chi Squere menunjukkan bahwa nilai p-value 0,000. Oleh karena $p$-value $<\alpha(0,05)$ artinya ada hubungan antara Pekerjaan ibu dengan Keberhasilan ASI Eksklusif di Puskesmas Umbulharjo I Yogyakarta. Hal ini menunjukan bahwa hipotesis yang menyatakan ada hubungan pekerjaan ibu dengan pemberian ASI eksklusif dapat diterima. Hal ini berarti ada hubungan antara pekerjaan ibu dengan pemberian ASI eksklusif di Puskesmas Umbulharjo I Kota Yogyakarta.

Hal ini sesuai dengan penelitian Asty (2008) yang menyatakan bahwa pekerjaan ibu dapat mempengaruhi ibu dalam memberikan ASI eksklusif apalagi ibu tidak memiliki pengetahuan mengenai ASI eksklusif. Ibu yang bekerja cenderung tidak memberikan ASI eksklusif pada bayi karena alasan pekerjaan yang menyebabkan cakupan pemberian ASI eksklusif tidak maksimal dan tidak sesuai dengan target yang diharapkan. Alasan yang biasanya muncul adalah tidak adanya waktu untuk memberikan ASI secara langsung, jarak tempat kerja yang jauh dari tempat tinggal, ibu tidak mngetahui cara memerah ASI, cara menyimpan ASI perah, dan bagaimana cara pemberian ASI perah.

Penelitian ini sesuai dengan pendapat Prasetyono (2012) bahwa faktor yang mempengaruhi pemberian ASI eksklusif adalah karena ibu bekerja diluar rumah sehingga tidak dapat memberikan ASI eksklusif selama enam bulan kepada bayinya. Hasil penelitian Indrawati (2012) juga menunjukan adanya hubungan status pekerjaan ibu dengan pemberian ASI esksklusif pada bayi usia 0-6 bulan. Dari 28 ibu bekerja hanya 4 orang ibu yang memberikan ASI eksklusif pada bayinya 
(14,3\%), sedangkan 12 ibu yang tidak bekerja, 9 orang ibu memberikan ASI eksklusif pada bayinya (75\%).

Demikian juga dengan hasil penelitian Weber, et al. (2011), menyatakan bahwa kembali bekerja adalah alasan utama berhenti menyusui, dari $60 \%$ wanita yang berniat terus menyusui namun hanya $40 \%$ yang menyusui. Hal ini sesuai dengan penelitian yang dilakukan Rahmawati (2010), menunjukan bahwa faktor dominan yang berpengaruh adalah status pekerjaan dengan nilai $\mathrm{p}=0,004$ yang menandakan bahwa ibu yang tidak bekerja berpeluang memberikan ASI eksklusif pada bayinya 4 kali lebih besar dibandingkan ibu bekerja.

d. Hubungan Dukungan keluarga dengan Keberhasilan ASI Ekslusif Puskesmas Umbulharjo I Yogyakarta

Tabel 10. Dukungan Keluarga dengan Keberhasilan ASI Ekslusif Puskesmas Umbulharjo I Yogyakarta

\begin{tabular}{ccccccccc}
\hline $\begin{array}{c}\text { Dukungan } \\
\text { Keluarga }\end{array}$ & F & Ya & ASI Ekslusif & Tidak & Total & P value & OR & CI \\
\hline $\begin{array}{c}\text { Mendukung } \\
\text { Tidak }\end{array}$ & 70 & $52,2 \%$ & 64 & $47,8 \%$ & 134 & 0,000 & 14,2 & $3,24-62,3$ \\
mendukung & 2 & $7,1 \%$ & 26 & $92,9 \%$ & 28 & & & \\
\hline
\end{tabular}

Berdasarkan tabel 10 dari Hasil uji Chi Square menunjukkan bahwa nilai $p$-value 0,000 . Oleh karena $p$-value $<\alpha(0,05)$ artinya ada hubungan antara Dukungan keluarga dengan Keberhasilan ASI Ekslusif Puskesmas Umbulharjo I Yogyakarta.

Hasil penelitian menemukan sebagian besar dukungan keluarga dalam kategori sedang sejumlah 70 responden (43,2\%), dukungan baik sejumlah 64 responden $(39,5 \%)$, dan dukungan kurang sejumlah 28 responden $(17,3 \%)$. Keluarga memiliki peran yang sangat menentukan dalam keberhasilan menyusui karena keluarga turut menentukan kelancaran reflek pengeluaran ASI yang sangat berpengaruh pada emosi ibu.

Teori Proverawati (2010) menyatakan bahwa masyarakat beranggapan menyusui hanya urusan ibu dan bayinya, kenyataannya faktor penting yang mendukung pemberian ASI eksklusif berasal dari pemberian dukungan oleh keluarga, sebagaimana yang sering kita dengar bahwa banyak istri yang takut untuk memberikan ASI karena khawatir bentuk payudaranya menjadi berubah dan tidak menarik lagi, sehingga dalam hal ini dorongan moril dari keluarga sebagai orang yang paling dekat dan dianggap sebagai pihak yang paling mampu memberikan pengaruh kepada ibu untuk memaksimalkan pemberian ASI eksklusif.

Dukungan atau sikap positif dari pasangan dan keluarga akan memberikan kekuatan tersendiri bagi ibu. Pada hakekatnya keluarga terutama suami diharapkan mampu berfungsi untuk mewujudkan proses pemberian ASI eksklusif. Rendahnya dukungan keluarga membuat ibu sering tidak bersemangat memberikan ASI kepada bayinya. Peningkatan dukungan keluarga berupa perhatian kepada ibu akan meningkatkan 
pikiran positif ibu, hal ini dapat meningkatkan refleks prolaktin dan refleks let down.

Hasil penelitian menemukan bahwa pemberian ASI eksklusif sebagian besar dukungan keluarga baik berhasil memberikan ASI eksklusif sebanyak 57 responden $(35,2 \%)$. Hasil penelitian didapatkan nilai $\mathrm{p}$-value sebesar $0.00<0.05$ maka Ha diterima dan $\mathrm{H} 0$ ditolak yang berarti terdapat hubungan antara dukungan keluarga dengan pemberian ASI eksklusif di Puskesmas Umbulharjo I Kota Yogyakarta.

Hasil penelitian menemukan bahwa dukungan keluarga yang baik mempengaruhi keberhasilan ASI eksklusif hal ini karena adanya faktor pendorong yaitu keluarga. Keluarga memiliki peran yang penting dalam memotivasi ibu untuk menyusui melalui dukungan secara emosional meliputi dukungan yang diwujudkan dalam bentuk afeksi, adanya kepercayaan, perhatian, mendengarkan dan didengarkan. Bentuk dukungan ini membuat ibu memiliki perasaan nyaman, yakin, diperdulikan dan dicintai oleh keluarga sehingga ibu dapat menghadapi masalah dengan baik.

Dukungan dari orang lain atau orang terdekat sangat berperan di dalam sukses tidaknya menyusui. Semakin besar dukungan yang didapatkan untuk terus menyusui maka akan semakin besar pula kemampuan untuk dapat bertahan untuk terus menyusui. Dalam hal ini dukungan keluarga sangat besar pengaruhnya, jika seorang ibu kurang mendapat dukungan dari keluarga akan lebih mudah dipengaruhi untuk beralih ke susu formula (Budiasih, 2008).

Hasil penelitian Trisnawati (2012) menunjukkan bahwa ada hubungan yang bermakna antara dukungan keluarga dengan pemberian ASI eksklusif di wilayah kerja Puskesmas Ngaliyan Semarang, presentase ibu yang memberikan ASI eksklusif dengan dukungan keluarga yang baik yaitu $(81,4 \%)$. Hal ini dikarenakan semakin tinggi memberikan dukungan maka ibu akan lebih termotivasi, semangat dan yakin selama menyusui.

e. Hubungan Pengetahuan dengan Keberhasilan ASI Ekslusif di Puskesmas Umbulharjo I Yogyakarta

Tabel 11. Tabulasi Silang Hubungan Pengetahuan dengan Kebrhasilan ASI Ekslusif di Puskesmas Umbulharjo I Yogyakarta

\begin{tabular}{ccccccccc}
\hline \multirow{2}{*}{ Pengetahuan } & \multicolumn{9}{c}{ Ya } & F Ekslusif & Tidak & Total & P value & OR & CI \\
& F & \% & F & \% & & & \\
\hline Tidak & 70 & $51,1 \%$ & 67 & $48,9 \%$ & 137 & 0,000 & 12,0 & $2,72-52,9$ \\
Ya & 2 & $8,0 \%$ & 23 & $92,0 \%$ & 25 & & & \\
\hline
\end{tabular}

Berdasarkan tabel 11 dari Hasil uji Chi Squere menunjukkan bahwa nilai $p$-value 0,00 Oleh karena $p$-value $<\alpha(0,05)$ artinya ada hubungan Pengetahuan dengan Keberhasilan ASI Ekslusif di Puskesmas Umbulharjo I Yogyakarta. 
Hasil penelitian menunjukkan bahwa sebagian besar responden tahu tentang ASI Ekslusif yaitu sebanyak 137 responden atau 84,6\%. Hasil uji Chi Squere menunjukkan bahwa nilai p-value 0,00 Oleh karena $p$-value $<\alpha(0,05)$ artinya ada hubungan Pengetahuan dengan Keberhasilan ASI Ekslusif di Puskesmas Umbulharjo I Yogyakarta.

Pengetahuan dan sikap merupakan konsep penting dari psikologi sosial yang membahas unsur sikap pada individu maupun kelompok. Pengetahuan dan Sikap merupakan bagian dari memahami proses kesadaran yang menentukan tindakan nyata dan tindakan yang mungkin dilakukan individu dalam kehidupan sosialnya (Wawan, 2011).

Berdasarkan uji statistic regresi logistic didapatkan $p$-value $=$ 0,006 dan nilai $\mathrm{OR}=9,42$ (CI: 1,89-46,9) dapat diartikan bahwa ibu yang tahu tentang ASI Ekslusif berpeluang 9,42 kali untuk berhasil dalam memberikan ASI Ekslusif dibandingkan ibu tidak tahu mengenai ASI Ekslusif.

Pengetahuan merupakan hasil stimulasi informasi yang diperhatikan dan diingat. Informasi tersebut bisa berasal dari pendidikan formal maupun non formal, percakapan, membaca, mendengarkan radio, menonton televisi dan pengalaman hidup. Menurut Notoadmodjo (2012), pengetahuan adalah hasil tahu dan ini terjadi karena seseorang melakukan pengindraan terhadap subyek tertentu. Pengetahuan seorang ibu mengenai ASI akan mendorong praktik pemberian ASI eksklusif kepada bayinya.

\section{Analisis Multivariat faktor-faktor yang mempengaruhi pemberian ASI Eksklusif}

Tabel 12. Hasil Analisis Regresi Logistik factor factor yang berhubungan dengan ASI Ekslusif

\begin{tabular}{lccc}
\hline \multicolumn{1}{c}{ Variabel } & P value & OR & CI $\mathbf{9 5 \%}$ \\
\hline Paritas & 0,632 & 1.24 & $0,51-3,00$ \\
Pendidikan ibu & 0,183 & 2,00 & $0,72-5,56$ \\
Pekerjaan ibu & 0,000 & 5,67 & $2,29-14,0$ \\
Dukungan keluarga & 0,109 & 3,87 & $0,73-20,34$ \\
Pengetahuan & 0,006 & 9,42 & $1,89-46,9$ \\
$\mathrm{R}^{2}$ & & & 0,360 \\
\hline
\end{tabular}

Berdasarkan tabel 12 hasil uji statistik regresi logistik didapatkan bahwa variabel yang paling mempengaruhi ASI Eksklusif adalah pekerjaan ibu. Hasil analisis didapatkan nilai OR sebesar 5,67 (95\% CI : 2,29-14,0) yang memiliki arti bahwa ibu yang tidak bekerja berpeluang 5,67 kali lebih besar untuk dapat memberikan ASI Eksklusif dibandingkan dengan ibu yang bekerja. Variabel kedua yang paling berpengaruh adalah variabel pengetahuan ibu dengan nilai uji statistic regresi logistic didapatkan $\mathrm{p}$-value $=0,006$ dan nilai $\mathrm{OR}=9,42(\mathrm{CI}: 1,89-46,9)$ dapat diartikan bahwa ibu yang tahu tentang ASI Ekslusif berpeluang 9,42 kali untuk berhasil dalam memberikan ASI Ekslusif dibandingkan ibu tidak tahu mengenai 


\section{KESIMPULAN}

Variabel yang paling berpengaruh adalah variabel pekerjaan ibu dengan nilai uji statistic regresi logistic didapatkan $p$-value $=0,000$ dan nilai $\mathrm{OR}=5,67$ (CI: 2,29-14,0) dapat diartikan bahwa ibu yang tidak bekerja berpeluang 5,67 kali untuk berhasil dalam memberikan ASI Ekslusif dibandingkan ibu yang bekerja. Variabel kedua yang paling berpengaruh adalah variabel pengetahuan ibu dengan nilai uji statistic regresi logistic didapatkan $p$-value $=0,006$ dan nilai $\mathrm{OR}=9,42$ (CI: 2,29-14,0) dapat diartikan bahwa ibu yang tahu tentang ASI Ekslusif berpeluang 9,42 kali untuk berhasil dalam memberikan ASI Ekslusif dibandingkan ibu tidak tahu mengenai ASI Ekslusif.

\section{DAFTAR PUSTAKA}

Asty, R. (2008). Hubungan Pekerjaan Ibu Dengan Tindakan Pemberian ASI Eksklusif Puskesmas Pancur Batu Deli Serdang. Skripsi Fakultas Kedokteran Universitas Sumatera Utara, Medan.http://hilalahmarjakarta.com/artikel/asi-untuk-bayi-kita, diakses tanggal 5 April 2017.

Budiasih, Sri. (2008). Hanbook Ibu Menyusui. Bandung: Karya Kita.

Dinas Kesehatan Daerah Istimewa Yogyakarta. (2015). Profil Kesehatan Daerah Istimewa Yogyakarta tahun 2015. Yogyakarta: Dinkes Daerah Istimewa Yogyakarta.

Dinas Kesehatan Kota Yogyakarta. (2016). Profil Kesehatan Kota Yogyakarta tahun 2016. Yogyakarta: Dinkes Kota Yogyakarta.

Dalimunthe, S. (2011). Faktor-Faktor Yang Mempengaruhi Produksi ASI. Skripsi Universitas Sumatra Utara : Medan. Diakses tanggal 5 April 2017 http://repository.usu.ac.id/bitstream/handle/123456789/66340/pdf?seque nce $=7 \&$ isAllowed $=\mathrm{y}$

Damayanti. (2010). Asiknya Minum ASI. Jakarta: PT Gramedia Pustaka Utama

Indrawati, A. (2012). Hubungan Status Pekerjaan Ibu dengan Pemberian Air Susu Ibu (ASI) Eksklusif Pada Bayi Saat Usia 0-6 Bulan di BPM Kota Semarang. Dinamika Kebidanan vol. 2 no. 2 Agustus 2012.

Kuntjoro, H. (2012). Dukungan Sosial Keluarga. Jakarta: EGC.

Notoatmodjo, S. (2012). Metodologi Penelitian Kesehatan. Jakarta: Rineka Cipta

Patel \& Gedam. (2013). Effect Back Massage on Lactation Among Postnatal Mothers. Internasional Journal of Medical Research dan Review, JanMar, 2013/ Vol 1/ Issue 1, Bhopal India diakses 5 November 2016.

Pawenrusi, E.P. (2011). Faktor-Faktor yang Berhubungan dengan Pemberian ASI Eksklusif di Kelurahan Temamaung, Makassar. Media Gizi Pangan, Vol. XI, Edisi 1, Januari - Juni 2011.

Pertiwi. (2012). Gambaran Faktor-faktor yang Mempengaruhi Pemberian ASI Eksklusif di Kelurahan Kunciran Indah Tangerang, Jakarta. Skripsi Universitas Indonesia. http://lib.ui.ac.id/file?file=digital/20312381S\%2043138Gambaran\%20fa ktor-full\%20text.pdf diakses tanggal 20 Mei 2017. 
Prasetyono, D. S. (2012). Buku Pintar ASI Eksklusif Pengenalan, Praktik, dan Kemanfaatan-Kemanfaatan. Yogyakarta : DIVA press.

Proverawati.(2012). Kapita Selekta ASI \& Menyusui.Yogyakarta: Nuha Medika.

Rahmawati. (2010). Faktor-faktor yang Mempengaruhi Pemberian ASI Eksklusif Pada Ibu Menyusui di Kelurahan Pandalangan Semarang Kecamatan Banyumunik. Skripsi STIKES Kusuma Husada Surakarta http://download.portalgaruda.org/article.php?article=119638\&val=5479 diakses tanggal 20 Mei 2017.

Rusmil, K. (2012). Pedoman Pelaksanaan, Deteksi dan Intervensi Dini Tumbuh Kembang Anak di Tingkat Pelayanan Dasar. Jakarta: Kementerian Kesehatan RI.

Trisnawati, Machmudah, Sobirun. (2012). Faktor-faktor yang berhubunga dengan pemberian ASI eksklusif di wilayah kerja Puskesmas Ngaliyan Semarang. http://pmb.stikestelogorejo.ac.id/ejournal/index.php/ilmukeperawatan/arti cle/view/116/141

Wahana Visi Indonesia. (2015). Aksi ASI: Ibu bekerja, ASI beraksi. Kasih Peduli.

Weber, et al. (2011). Female Employess' Perceptions Of Organisation Support for Breastfeeding at work: Findings From An Australian Health Service Workplace. International Breasfeeding Journal. 6:1.

WHO. (2010). Infant And Young Child Feeding : ISBN http://www.who.int/nutrition/publications/infantfeeding/9241562218/en/. Akses tanggal 25 November 2015.

Winkjosastro. (2010). Buku panduan praktis Pelayanan Kesehatan Maternal dan Neonatal, edisi I. Jakarta: Bina Pustaka

Zanardo, et al. (2009). Effect of postpartum Anxiety On the Colostral Milk Beta Endorphin Concentrations Of Breastfeeding Mothers. Italy: The Journal of Obstetry and Gynecology. Vol. 21 (2): 130-4. 